


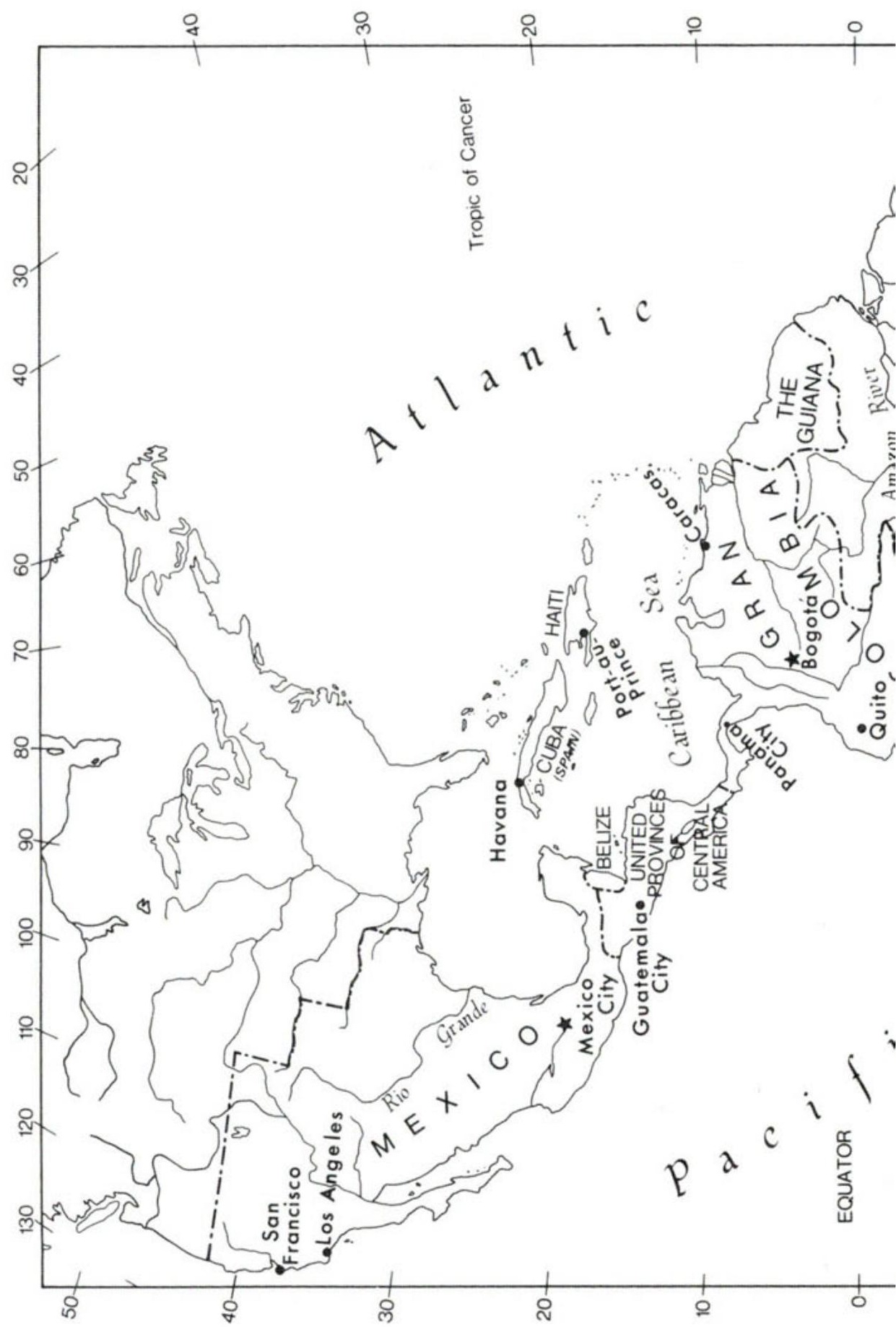



THE POVERTY OF PROGRESS 



\title{
THE POVERTY OF PROGRESS
}

\section{Latin America in the Nineteenth Century}

\author{
E. Bradford Burns
}

UNIVERSITY OF CALIFORNIA PRESS

Berkeley Los Angeles London 
University of California Press

Berkeley and Los Angeles, California

University of California Press, Ltd.

London, England

Copyright (C) 1980 by The Regents

of the University of California

First Paperback Printing 1983

ISBN 0-520-05078-9

Library of Congress Cataloging in Publication Data

Burns, E Bradford.

The poverty of progress.

Includes index.

1. Latin America - History-1830-1898.

2. Latin America-Social conditions. 3. Latin America-Economic conditions. I. Title. F1413.B87 980'.03

$80-51236$

Printed in the United States of America 
"Peoples of Europe, if only the sea and wind had never brought you to us! $\mathrm{Ah}$, it was not for nothing that nature extended between us that flat expanse of waters."

- Words of the Indian Cacambo, Basilio de Gama, O Uraguai "The incorporation of America into 'Western Civilization' was marked by violence first against the Indian population and later against the black slaves and the mestizo population."

- Alvaro Tirado Mejía, Aspectos Sociales de las Guerras Civiles en Colombia

"And at last the philosophy of progress shows its true face: a featureless blank. We know now that the kingdom of progress is not of this world: the paradise it promises us is in the future, a future that is impalpable, unreachable, perpetual. Progress has peopled history with the marvels and monsters of technology but it has depopulated the life of man. It has given us more things but not more being. . . . How can we not turn away and seek another mode of development? It is an urgent task that requires both science and imagination, both honesty and sensitivity; a task without precedence, because all of the modes of development that we know, whether they come from the West or the East, lead to disaster. Under the present circumstances the race toward development is mere haste to reach ruin."

- Octavio Paz, The Other Mexico: Critique of the Pyramid

One of the reasons I had wanted to go back to a traditional peasant society was to see if, as Fromm and Maccoby had suggested, there was a higher level of productiveness and a greater enjoyment of life than in the mestizo village which they had studied and with which I was also quite familiar. Again, as I have repeatedly observed, there does in fact appear to be a greater enjoyment of life among the Chan Kom women than there had been observed in Las Cuevas, or in most mestizo villages, or for that matter, in most communities in the U.S.A. The women constantly display their sense of pride and pleasure in most aspects of their lives, conveying a feeling of dignity as well as pride. And, more importantly, there is a sense of harmony with each other, with nature, within their total world." -Mary Lindsay Elendorf,

Nine Mayan Women: A Village Faces Change

"The quality of human existence is the ultimate measure of development." 
